\title{
Methods used to reveal genetic diversity in the colony-forming prymnesiophytes Phaeocystis antarctica, $P$. globosa and $P$. pouchetii-preliminary results
}

\author{
Steffi Gaebler • Paul K. Hayes • \\ Linda K. Medlin
}

Received: 12 October 2005 / Accepted: 17 March 2006 / Published online: 12 April 2007

(C) Springer Science+Business Media B.V. 2007

\begin{abstract}
Previous work on the genetic diversity of Phaeocystis used ribosomal DNA and internal transcribed spacer (ITS) sequence analyses to show that there is substantial inter- and intraspecific variation within the genus. First attempts to trace the biogeographical history of strains in Antarctic coastal waters were based on a comparison of ITS sequences. To gain deeper insights into the population structure and bloom dynamics of this microalga it is necessary to quantify the genetic diversity within populations of $P$. antarctica from different locations (i.e., each of the three major gyres in the Antarctic continental waters) and to calculate the gene flow between them. Here we describe methods to quantify genetic diversity and our preliminary results for $P$. antarctica in comparison to two other colonial species: $P$. globosa and $P$. pouchetii. For this study of genetic diversity, two fingerprinting techniques were used. First, amplified fragment-length polymorphisms (AFLPs) were established as a
\end{abstract}

S. Gaebler $(\bowtie) \cdot$ L. K. Medlin

Alfred Wegener Institute for Polar

and Marine Research, Am Handelshafen 12,

27570 Bremerhaven, Germany

e-mail: sgaebler@awi-bremerhaven.de

P. K. Hayes

School of Biological Sciences, University of Bristol,

Woodland Road, Bristol, BS8 1UG, UK pre-screening tool to assess clone diversity and to select divergent clones prior to physiological investigations. Second, the more-powerful microsatellite markers were established to assess population structure and biogeography more accurately. Results show differences in the AFLP patterns between isolates of $P$. antarctica from different regions, and that a wide variety of microsatellite motifs could be obtained from the three Phaeocystis species.

Keywords AFLP · Microsatellite marker · Phaeocystis $\cdot$ P. antarctica $\cdot$ P. globosa .

P. pouchetii

\section{Introduction}

The genus Phaeocystis was erected by Lagerheim (1893/1896) to accommodate the colonial alga Tetraspora pouchetii described by Hariot in Pouchet (1892). The newly combined species, Phaeocystis pouchetii, can be found in Arctic waters. Two other colonial species were described soon after that: P. globosa by Scherffel $(1899,1900)$ from temperate waters and $P$. antarctica by Karsten (1905) from the Antarctic. Kornmann (1955) expressed doubt that these species were separate and lumped up all colonial species into a single taxon Phaeocystis pouchetii. Despite physiological studies (Baumann and Jahnke 1986; Jahnke 
and Baumann 1986, 1987; Jahnke 1989) that confirmed the separation of these taxa, it took a molecular study (Medlin et al. 1994) to end the controversy over the validity of the three colonial species. Since that time further molecular studies using other gene loci have confirmed the separation of these taxa (Lange et al. 2002) and other species have also been included in the genus (Zingone et al. 1999).

Phaeocystis is known to play an important role in ecology and biogeochemistry because it is distributed worldwide and forms massive blooms. Its blooms can fix a high amount $\mathrm{CO}_{2}$ and produce a substantial amount of dimethylsulfoniopropionate (DMSP), which is the biological precursor of sphere dimethylsulfide (DMS) (Smith et al. 1991; Stefels 1997; Arrigo 1999; Verity and Smetacek 1996). $P$. antarctica is widely distributed in the Southern Ocean where it is among the most abuntributor to organic matter vertical fluxes. It is known from physiological studies from many phytoplankton species that there is a high variability among strains for every trait examined (Wood and Leatham 1992). Thus, a study of the genetic diversity and gene flow among Phaeocystis strains around the Antarctic is both timely and necessary. To pursue this we chose two techniques to assess the genetic diversity within and among the climatically important trace gas of the atmodant primary producers and is thus a major con-

Phaeocystis spp. One technique, amplified fragment-length polymorphisms, (AFLPs) provides a rapid means to screen the entire genome for polymorphic genetic loci as a pre-screening tool to select most divergent clones for physiological investigations, whereas analysis of microsatellite loci provides a more rigorous method by which population genetic statistics can be applied to assess the genetic diversity in populations and gene flow between them. Both of these techniques will be applied to each of the three colonial species, but we report here preliminary data to establish these techniques for $P$. antarctica.

\section{Amplified fragment length polymorphism}

The AFLP technique developed by Vos et al. (1995) was used as described in John et al. (2004). Genomic DNA of 48 Phaeocystis strains previously extracted in earlier studies (Medlin et al. 1994; Lange et al. 2002) was digested over night at $37^{\circ} \mathrm{C}$ with two restriction enzymes (EcoRI and MseI, New England BioLabs, Frankfurt a. Main, Germany). This enzyme combination consists of a rare (EcoRI, six-base-pair recognition sequence) and a frequent (MseI, four-base-pair recognition sequence) cutter. Subsequent to digestion, sitespecific adapters were ligated to the ends of the restriction fragments (see Fig. 1).

Fig. 1 Schematic diagram showing the construction of the AFLP fragments (from Müller 2005)

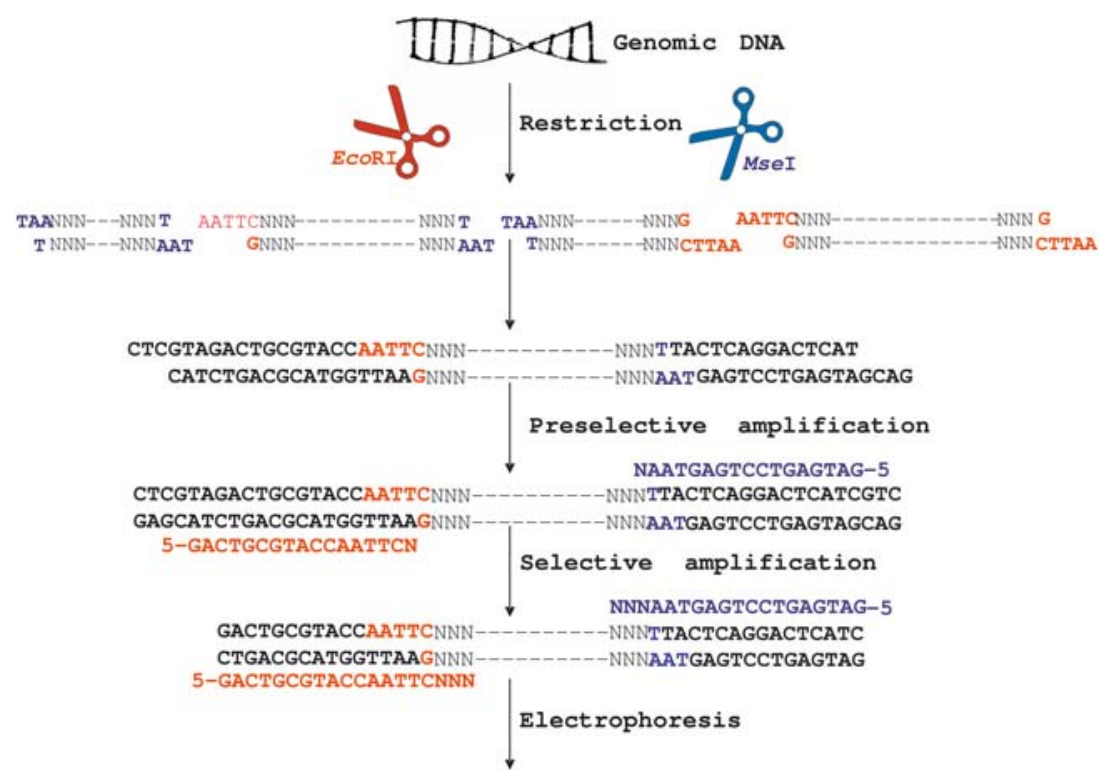


To amplify a subset of DNA restriction fragments, one to six additional nucleotides can be added to the $3^{\prime}$-end of primers complementary to the adapter and restriction site sequences (Vos et al. 1995). With two additional polymerase chain reaction (PCR) steps, the preselective and the selective amplification, only a specific subset of fragments is amplified, so that the number of the resulting PCR products provides sufficient resolution among the strains. Too many fragments make analysis difficult, whereas too few do not provide enough resolution. A primer set with one selective nucleotide per primer for the preselective amplification and different numbers of selective nucleotides per primer for the selective amplification were compared (Table 1). To be able to visualize the amplification products one primer was fluorescently labelled for the second amplification $\quad(E c o$ RI*6Fam + NNN, Applied Biosystems, Germany). After the second amplification, the samples were electrophoresed using a capillary sequencer (ABI PRISM 3100 AVANT, Applied Biosystems, Germany). For this part of the AFLP optimization, 10 primer sets for the selective amplification were tested using only four out of the 48 different $P$. antarctica isolates (Table 3). In Fig. 2 eight of these primer sets are compared for the isolate $P$. antarctica A1-3 because two of them produced no products. For all four isolates tested it was found that fewer selective nucleotides used in the second amplification step provided better resolution. Primer set $M s e \mathrm{I}+\mathbf{C T} / E c o \mathrm{RI}+\mathbf{A T}$ seemed to be the best choice because it not only gave greater resolution of the fragment pattern from zero to $500 \mathrm{bp}$ (base pairs), but also more-intense fragments (Fig. 2).

Table 1 Selective nucleotides (SN) used for selective amplification. $\mathrm{X}=$ these primer sets have been used

\begin{tabular}{lllll}
\hline Primer & & \multicolumn{3}{l}{ MseI + SN } \\
\cline { 3 - 4 } & & $\mathrm{C}$ & $\mathrm{CC}$ & $\mathrm{CT}$ \\
\hline EcoR1 + SN & AA & & & \\
& AC & & & $\mathrm{X}$ \\
& AG & & & $\mathrm{X}$ \\
& AT & & & $\mathrm{X}$ \\
& AAG & $\mathrm{X}$ & $\mathrm{X}$ & $\mathrm{X}$ \\
& ATG & $\mathrm{X}$ & $\mathrm{X}$ & $\mathrm{X}$ \\
\hline
\end{tabular}

Fragment patterns for the Phaeocystis isolates were compared for this primer set (Fig. 3) and for primer set $M s e \mathrm{I}+\mathbf{C T} / E c o \mathrm{RI}+\mathbf{A A}$ (Fig. 4). Differences and similarities among the isolates were easily noted by the presence of bands shared between the isolates. Differences in the genetic fingerprints could result from their biogeographical distance and the supposed gene flow around the Antarctic waters. Comparing Figs. 3 and 4 the band patterns of all isolates are distinct from one another. These differences are more clearly shown with the primer set $M s e I+\mathbf{C T} /$ $E c o$ RI + AT (Fig. 3). From the fragment patterns of the $P$. antarctica isolates obtained with this primer set, a distance matrix (fragment presence/ absence) was manually calculated for amplification fragments of between $100 \mathrm{bp}$ and $500 \mathrm{bp}$ only to illustrate the similarity and differences among these four strains. Fragment lengths from $100 \mathrm{bp}$ to $500 \mathrm{bp}$ were arbitrarily chosen because this size range appeared to present those lengths that could be most easily scored. The presence/ absence of 41 bands was scored between these lengths. Peak heights below 200 fluorescence units (see Figs. 2, 3 and 4) were ignored: fragment lengths $<100$ bp were not clearly resolved. Maximum parsimony analysis of the AFLP data set (Fig. 5: PAUP, Swofford 2002) shows that genetic diversity of $P$. antarctica in the Antarctic region is highly variable. The isolate $P$. antarctica SK22 from the Antarctic circumpolar current (ACC) (Fig. 6) was defined as the outgroup based on internal transcribed spacer (ITS) sequence data (Lange et al. 2002). Isolate SK21 (Weddell Sea) and D5 (Prydz Bay) seem to be more closely related to each other than to A1-3 (Prydz Bay), which, to judge by its branch length, contains more unique fragment lengths. The divergence of A1-3 (Prydz Bay) before the divergence of SK21 (Weddell Sea) and D5 (Prydz Bay) was also recovered in the ITS analysis of Lange et al. (2002). The next step is to increase the resolution of the amplification patterns and to optimize primer sets for all Phaeocystis strains. Reproducibility of the AFLP technique must be assessed by performing replicate reactions using more than one DNA isolation from the same strain; however we have, with our limited strain analysis, recovered the same tree topology as the 
Fig. 2 AFLP electropherograms (resolution from 50-350 base pairs) of eight different primer sets for $P$. antarctica A1-3 (Prydz Bay, Fig. 6)
Comparison of primer sets for $P$. antarctica $\mathrm{A} 1-3$

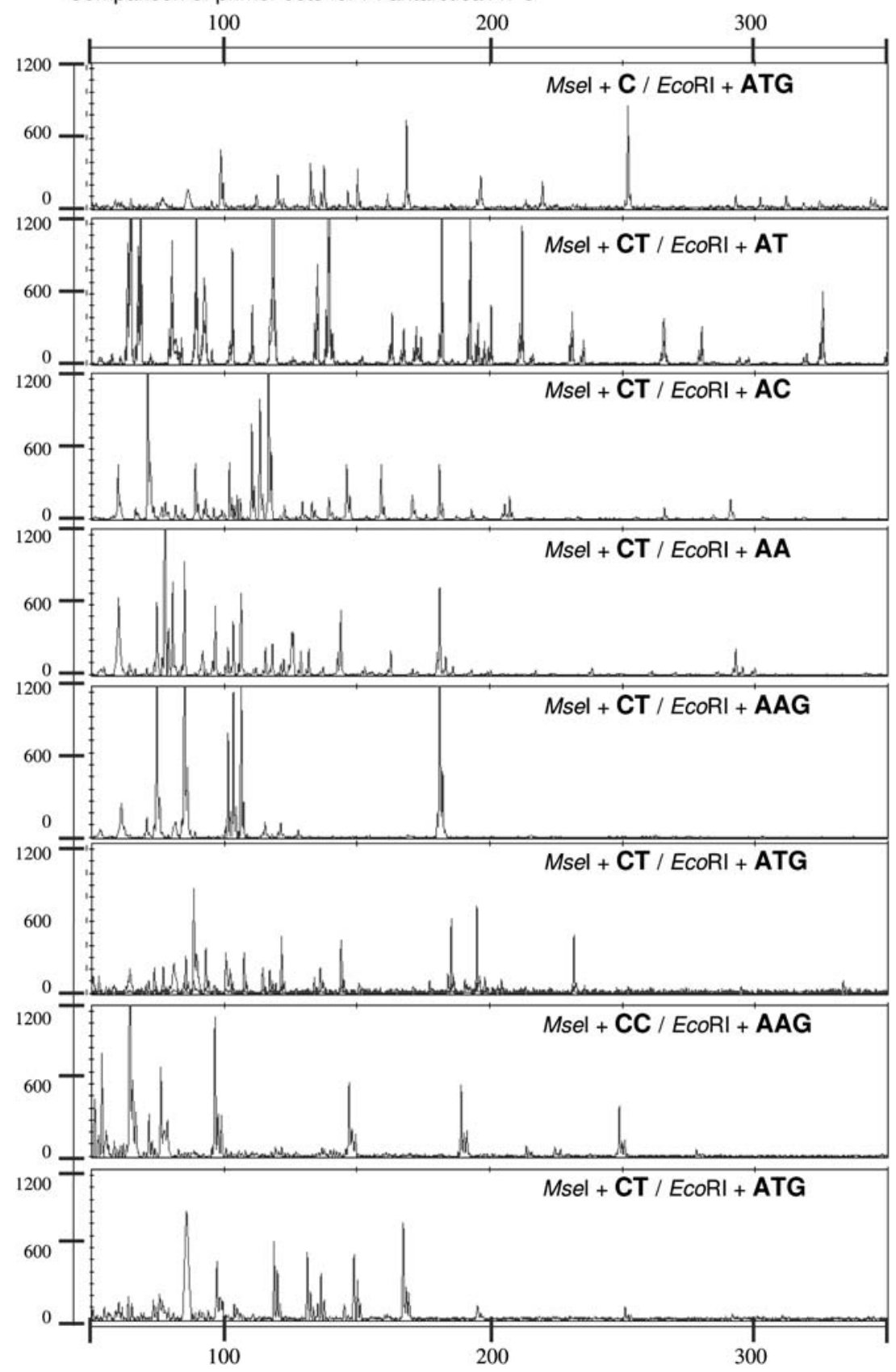

ITS analysis with more strains (Lange et al. 2002).

Microsatellite markers

Total DNA was isolated from $P$. globosa (CCMP1528), $P$. pouchetii (SK 34) and $P$. antarctica
(SK 23) (Table 2) using a modified hexadecyltrimethylammonium bromide (CTAB) extraction protocol (Doyle and Doyle 1990; Lange 1997). Nuclear DNA was purified by ultracentrifugation through a caesium chloride-ethidium bromide density gradient (Lange 1997). This DNA was used to create enriched microsatellite libraries 


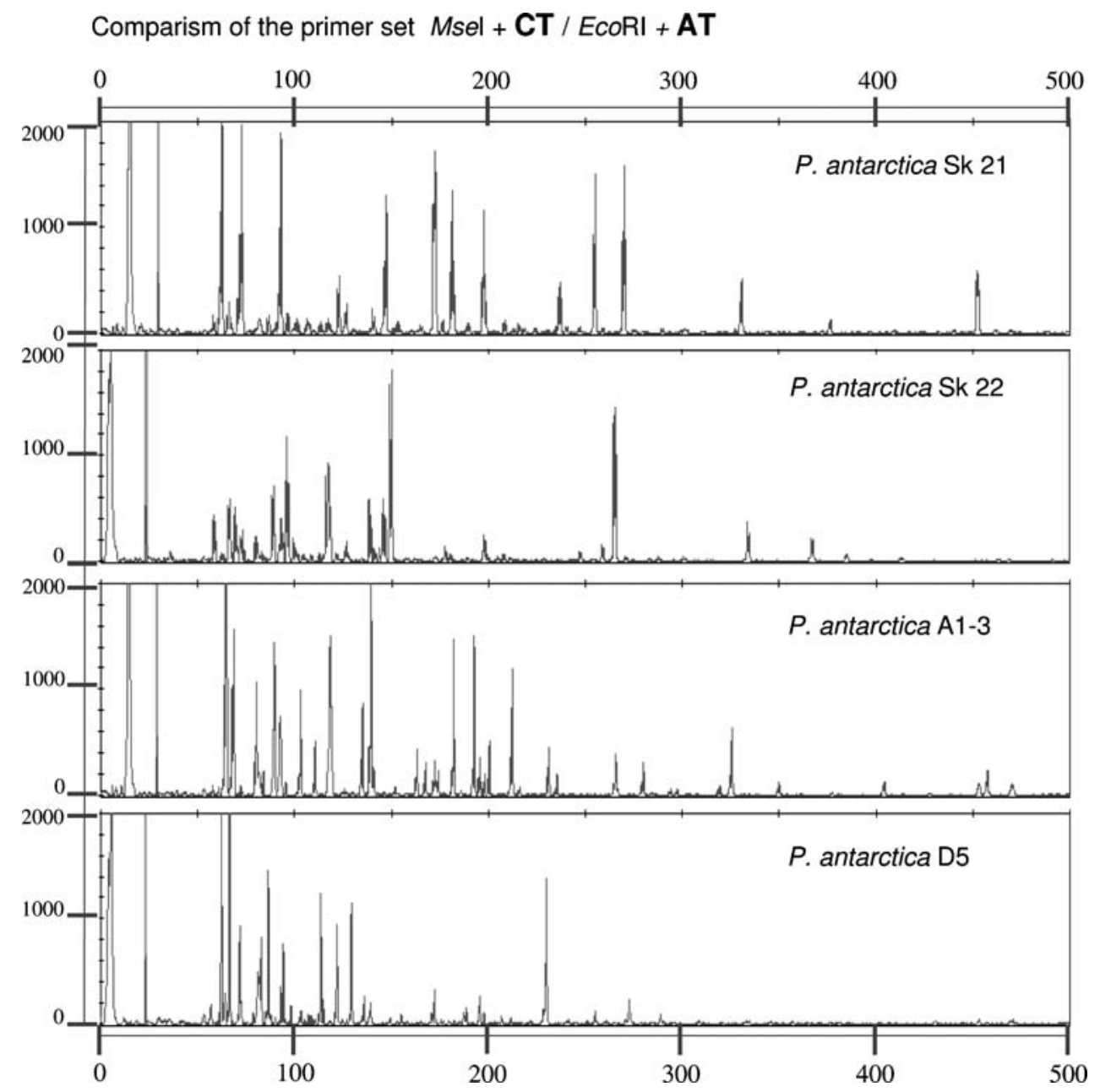

Fig. 3 AFLP electropherograms (resolution from 0-500 base pairs) of the primer set MseI + CT/EcoRI + AT for the P. antarctica isolates (Table 2)

for the three colony-forming species. The protocol for the construction of these libraries was modified slightly from that of Evans and Hayes (2004), which was based on Edwards et al. (1996). Two biotinylated microsatellite oligonucleotides Bio-GA and Bio-GT (Thermo Electron $\mathrm{GmbH}$, Germany) were immobilized on magnetic beads (Dynabeads, Dynal Biotech Invitrogen, Germany). These oligonucleotides were used to bind and capture CT and CA motifs in restriction fragments to which oligonucleotide adapters had been ligated. A second round of enrichment was achieved by recapturing postamplification Dynabead products and repeating all subsequent steps in the protocol (Evans and
Hayes 2004). Enrichment PCR fragments were cloned into TOPO vector $\left(\mathrm{pCR}^{\circledR}\right.$ 2.1-Topo, Invitrogen, Germany) and plasmid DNA was isolated from Escherichia coli using the minipreparation-scale Wizard $^{\mathrm{TM}}$ Minipreps DNA Purification System (Serva, Heidelberg, Germany). The resultant Miniprep DNA was washed with $70 \%$ EtOH and resuspended in $\mathrm{H}_{2} \mathrm{O}$. Cloned fragments were directly sequenced using the BigDye ${ }^{\circledR}$ Terminator v3.1 Cycle sequencing Kit (Applied Biosystems, Germany) and the vector primer set: M13 HedgeF-5'-GTTTTCCCA GTCACGACGTTG 3'; M13 HedgeR-5'-TGA GCGGATAACAATTTCACACAG 3' (Operon, Germany). 
Comparism of the primer set $\mathrm{Msel}+\mathrm{CT} / \mathrm{EcoRI}+\mathbf{A A}$

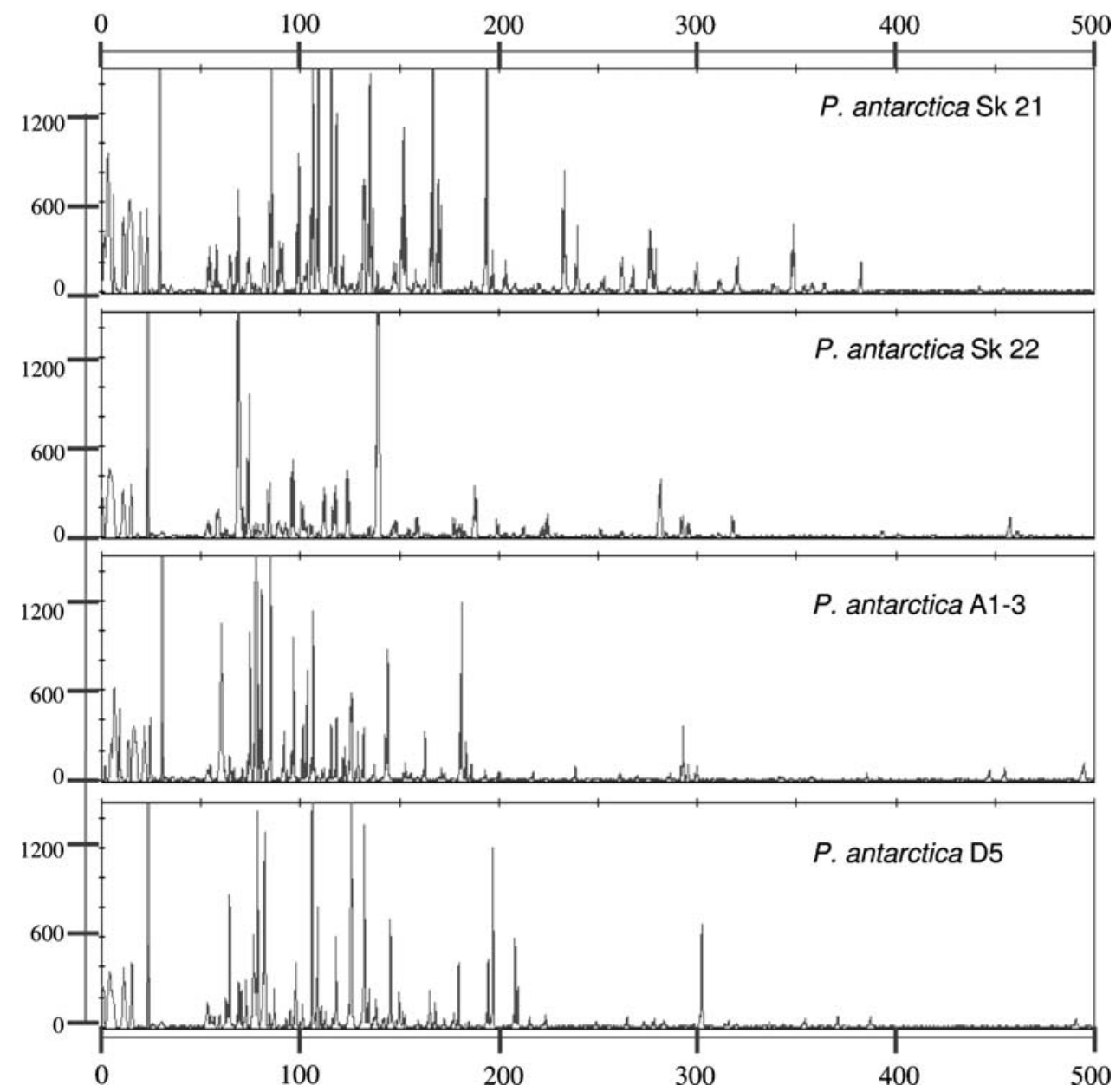

Fig. 4 AFLP electropherograms (resolution from 0-500 base pairs) of the primer set $M s e \mathrm{I}+\mathbf{C T} / E c o$ RI $+\mathbf{A A}$ for the $P$. antarctica isolates (Table 2)

Eighteen cloned fragments from $P$. antarctica and 17 cloned fragments from both P. globosa and $P$. pouchetii were sequenced. Of these, 14 cloned fragments from $P$. antarctica and nine cloned fragments from P. globosa and P. pouchetii contained repeating sequence motifs. Preliminary results indicate a very high variability in the microsatellite motifs (Table 3). At least 50 further clones will be sequenced from each species to allow the characterization of additional microsatellite repeats and their flanking sequences. Primer pairs that anneal within the flanking sequences either side of the microsatellite repeats will be designed with the program PRIMER 3.0 (http://www.frodo.wi.mit.edu/cgi-bin/ primer3/primer3_www.cgi). Of the microsatellite motifs shown in Table 3 , only the simple repeats will be investigated further: complicated nested motifs are too difficult to analyse.

These initial results suggest that Phaeocystis is genetically diverse and that this diversity can be quantified and interpreted based on the use of AFLPs and MS. With the microsatellites, we will be able to calculate gene flow around the Antarctic for P. antarctica. 


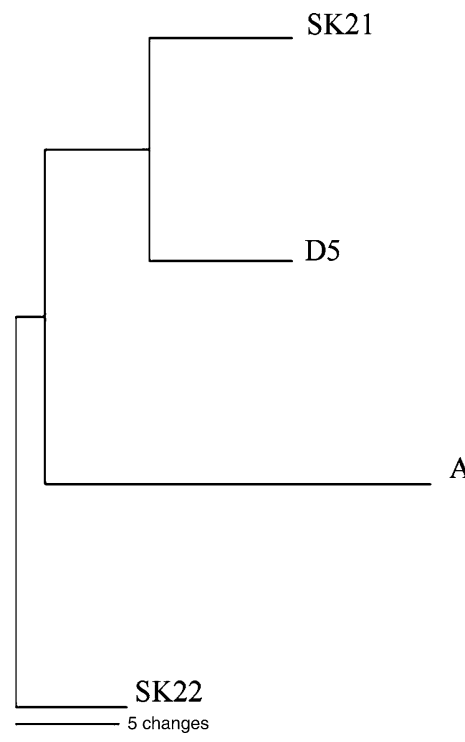

Fig. 5 Most parsimonious phylogram of \pm presence of fragment lengths of the $P$. antarctica isolates obtained from the primer set $M s e \mathrm{I}+\mathbf{C T} / E c o \mathrm{RI}+\mathbf{A T}$

A1-3
Table 2 Algal species used to test best primer set and to create microsatellite-enriched libraries

\begin{tabular}{lll}
\hline Strains & $\begin{array}{l}\text { Culture number, } \\
\text { Culture facility }{ }^{\mathrm{b}, \mathrm{c}, \mathrm{d}}\end{array}$ & $\begin{array}{l}\text { Geographic } \\
\text { origin }\end{array}$ \\
\hline
\end{tabular}

\begin{tabular}{ll}
\hline P. antarctica & $\mathrm{SK} 21^{\mathrm{c}}$ \\
P. antarctica & $\mathrm{SK} 22^{\mathrm{a}, \mathrm{c}}$ \\
P. antarctica & $\mathrm{A} 1-3^{\mathrm{a}, \mathrm{b}}$ \\
P. antarctica & $\mathrm{D} 5^{\mathrm{a}, \mathrm{b}}$
\end{tabular}

$\begin{array}{ll}\text { P. } \text { globosa }^{\mathrm{e}} & \text { CCMP1528 }^{\mathrm{d}} \\ \text { P. pouchetii } & \text { SK } 34^{\mathrm{a}, \mathrm{b}}\end{array}$

P. antarctica $^{\mathrm{e}}$ SK $23^{\mathrm{a}, \mathrm{b}}$

Antarctica, $65^{\circ} 15^{\prime} \mathrm{S}, 39^{\circ} 22^{\prime} \mathrm{W}$

Antarctica, $54^{\circ} 20^{\prime} \mathrm{S}, 3^{\circ} 20^{\prime} \mathrm{W}$

Antarctica, $63^{\circ} 11.5^{\prime} \mathrm{S}, 85^{\circ} 45.3^{\prime} \mathrm{E}$

Antarctica,

$68^{\circ} 47.5^{\prime} \mathrm{S}, 73^{\circ} 30.2^{\prime} \mathrm{E}$

Galapagos

Greenland Sea,

East Greenland current

Antarctica, $63^{\circ} 15^{\prime} \mathrm{S}, 58^{\circ} 20^{\prime} \mathrm{W}$

a Culture no longer available

b CSIRO Division of Fisheries, Hobart, Tasmania, Australia

c Alfred-Wegener-Institute for Polar and Marine Research, Am Handelshafen 12, Bremerhaven, Germany

d Proviasoli-Guillard Culture Center for Marine Phytoplankton, Bigelow Laboratory for Ocean Sciences, West Boothbay Harbour, Maine, USA

e Used for microsatellite-enriched library
Fig. 6 Geographic origin of the four $P$. antarctica strains (Table 2). To indicate the position of the Antarctic circumpolar current (ACC) encircling the Antarctic a schematic presentation was chosen (Lange et al. 2002; Olbers et al. 1962). [1: SK21, 2: SK22, 3: D5, 4: A1-3]

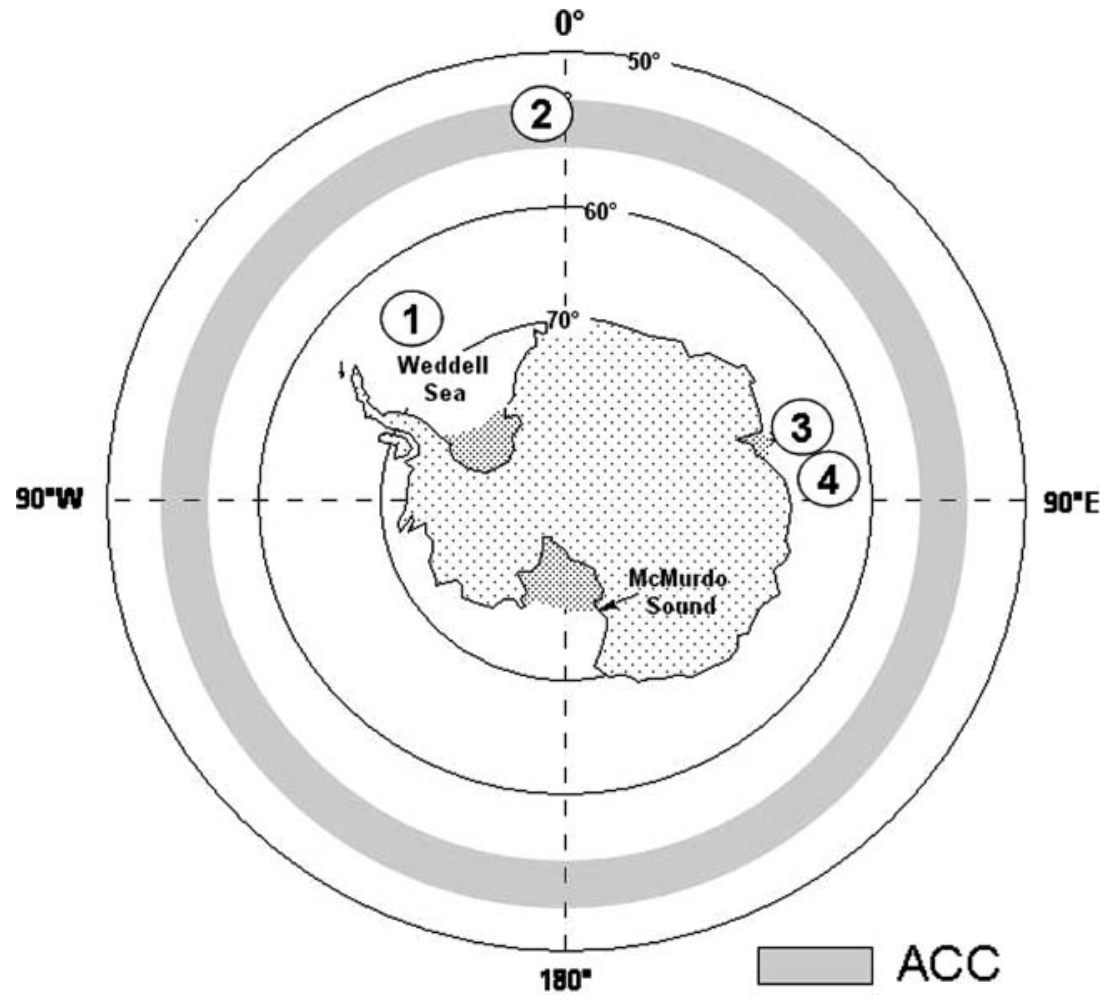


Table 3 Microsatellite (MS) motifs of the investigated Phaeocystis strains. Some clones contained multiple motifs

\begin{tabular}{|c|c|c|c|}
\hline \multicolumn{2}{|c|}{ Microsatellite motifs $P$. globosa } & P. pouchetit & P. antarctica \\
\hline $\begin{array}{l}(\mathrm{TG})_{n} \\
(\mathrm{CA})_{n} \\
(\mathrm{GA})_{n} \\
(\mathrm{TC})_{n} \\
(\mathrm{CAA})_{n} \\
(\mathrm{TTAC})_{n} \\
(\mathrm{GCTC})_{n} \\
(\mathrm{TATG})_{n} \\
{\left[(\mathrm{TG})_{n}(\mathrm{AG})_{n}\right]_{n}} \\
{\left[(\mathrm{CA})_{n}(\mathrm{TA})_{n}\right]_{n}} \\
(\mathrm{TTAGGG})_{n} \\
{\left[(\mathrm{TG})_{n} \mathrm{CG}(\mathrm{TG})_{n}\right]_{n}} \\
{\left[\mathrm{TTT}(\mathrm{GT})_{n} \mathrm{GC}\right]_{n}}\end{array}$ & $\begin{array}{l}1 \\
1 \\
3 \\
17 \text { clones } \\
9 \text { with MS }\end{array}$ & $\begin{array}{l}17 \text { clones } \\
9 \text { with MS }\end{array}$ & $\begin{array}{l}18 \text { clones } \\
14 \text { with MS }\end{array}$ \\
\hline
\end{tabular}

Acknowledgement This research was funded by the German Science Foundation (DFG) through a postgraduate research fellowship (ME 1480/2).

\section{References}

Arrigo KR, Robinson DH, Worthen DL, Dunbar RB, DiTullio GR, van Woert M, Lizotte MP (1999) Phytoplankton community structure and the drawdown of nutrients and $\mathrm{CO}_{2}$ in the Southern Ocean. Science 283:365-367

Baumann MEM, Jahnke J (1986) Marine Planktonalgen der Arktis. I. Die Haptophycee Phaeocystis pouchetii. Mikrokosmos 75:262-265

Doyle JJ, Doyle JL (1990) Isolation of plant DNA from fresh tissue. Focus 12:13-15

Edwards KJ, Barker JHA, Daly A, Jones C, Karp A (1996) Microsatellite libraries enriched for several microsatellite sequences in plants. Biotechniques 20:758-760

Evans KM, Hayes PK (2004) Microsatellite markers for the cosmopolitan marine diatom Pseudo-nitzschia pungens. Mol Ecol Note 4:125-126

Jahnke J, Baumann MEM (1986) Die marine Planktonalge Phaeocystis globosa: eine Massenform unserer Küstengewässer. Mikrokosmos 75:357-359

Jahnke J, Baumann MEM (1987) Differentiation between Phaeocystis pouchetii (Har.) Lagerheim and Phaeocystis globosa Scherffel I. Colony shapes and temperature tolerances. Hydrobiol Bull 21:141147

Jahnke J (1989) The light and temperature dependence of growth rate and elemental composition of Phaeocystis globosa Scherffel and P. pouchetii (Har.) Lagerh. in batch cultures. Neth J Sea Res 23:15-21

John U, Groben R, Beszteri B, Medlin LK (2004) Utility of Amplified Fragment Length Polymorphisms (AFLP) to analyse genetic structures within the $\mathrm{Al}$ - exandrium tamarense species complex. Protist 155:169-179

Karsten G (1905) Das Phytoplankton des Antarktischen Meeres nach dem Material der deutschen TiefseeExpedition 1898-1899. In: Chun C (ed) Wissenschaftliche Ergebnisse der deutschen Tiefsee-Expedition auf dem Dampfer "Valdivia" 1898-1899. Gustaf Fischer Verlag, Jena

Kornmann P (1955) Beobachtungen an Phaeocystis-Kulturen. Helgoländer wiss. Meeresunters 5:218-233

Lagerheim G (1893) Phaeocystis, nov. gen., grundadt pa Tetraspora Poucheti Har. Botaniska Notiser. 32-33

Lagerheim G (1896) Über Phaeocystis Poucheti (Har.) Lagerh., eine Plankton-Flagellate. Öfvers. af Vet. Akad Förhandl 53:277-288

Lange M (1997) Phylogeny and Taxonomy of the genus Phaeocystis (Prymnesiophyceae). Dissertation, University of Bremen, Germany, $170 \mathrm{pp}$

Lange M, Chen Y, Medlin LK (2002) Molecular genetic delineation of Phaeocystis species (Prymnesiophyceae) using coding and non-coding regions of nuclear and plastid genomes. Eur J Phycol 37:77-92

Medlin LK, Lange M, Baumann MEM (1994) Genetic differentiation among three colony-forming species of Phaeocystis. Phycologia 33:199-212

Müller J (2005) Genetic fingerprints of microalgal culture strains: amplified fragment length polymorphism (AFLP) for investigations below the species level. Dissertation, University of Goettingen, Germany, $100 \mathrm{pp}$

Olbers D, Gouretski V, Seiss G, Shröter J (1962) Hydrographic Atlas of the Southern Ocean. Druckhaus Nord, Bremerhaven, 82 plates

Pouchet MG (1892) Sur une algue pélagique nouvelle. Compt. Rend. Hebd. Séances Mém. Soc Biol 44:34-36

Scherffel A (1899) Phaeocystis globosa n.sp. (Vorläufige Mitteilung). Berichte der Deutschen Botanischen Gesellschaft 17:317-318

Scherffel A (1900) Phaeocystis globosa nov. spec. nebst einigen Betrachtungen, Über die Phylogenie niederer, insbesondere brauner Organismen. Wissenschaftliche Meeresuntersuchungen Abteilung Helgoland N.F. Bd. 4:1-29

Smith WO, Codispoti LA, Nelson DM, Manley T, Buskey EJ, Niebauer HJ, Cota GF (1991) Importance of Phaeocystis blooms in the high-latitude ocean carbon cycle. Nature 352:514-516

Stefels J (1997) The smell of the Sea. Production of dimethylsulphoniopropionate and its conversion into dimethylsulphide by the marine phytoplankton genus Phaeocystis. Dissertation, University of Groningen

Swofford DL (2002) PAUP*: Phylogenetic Analysis Using Parsimony (and Other Methods) 4.0 Beta, Florida State University, CD-ROM

Verity PG, Smetacek V (1996) Organism life cycles, predation, and the structure of marine pelagic ecosystems. Mar Ecol Prog Ser 130:277-293

Vos P, Hogers R, Bleeker M, Reijans M, Vandelee T, Hornes M, Frijters A, Pot J, Peleman J, Kuiper M, Zabeau M (1995) AFLP - a new technique for DNA fingerprinting. Nucleic Acids Res 23:4407-4414 
Wood AM, Leatham T (1992) The species concept in phytoplankton ecology. J Phycol 28:723-729

Zingone A, Crétiennot-Dinet MJ, Lange M, Medlin LK (1999) Morphological and genetic characterisation of
Phaeocystis cordata and P. jahnii (Prymnesiophyceae), two new species from the Mediterranean Sea. J Phycol 35:1322-1337 